Volume 1 Nomor 1 Tahun 2021

Halaman $18 \mathrm{~s} / \mathrm{d} 29$

Available Online at https : https://jurnal.unsur.ac.id/jubis

\title{
PENGARUH KOMPENSASI DAN FLEKSIBILITAS DRIVER GOJEK TERHADAP KINERJA DENGAN KEPUASAN KERJA SEBAGAI VARIABEL INTER VENING PADA PT GOJEK INDONESIA CABANG SAMARINDA
}

\author{
Luis Preselliya Siregar ${ }^{1}$, Adietya Arie Hetami ${ }^{2}$, Wira Bharata ${ }^{3}$ \\ Universitas Mulawarman, Jl. Kuaro, Gn. Kelua, Kec. Samarinda Ulu \\ E-mail: presellivaluis@gmail.com
}

\begin{tabular}{|l|l|l|}
\hline Masuk: 16 Juni 2021 & Penerimaan: 17 Juni 2021 & Publikasi: 28 Juni 2021 \\
\hline
\end{tabular}

\begin{abstract}
ABSTRAK
Penelitian ini bertujuan untuk mengetahui pengaruh variabel bebas yang terdiri dari Kompensasi (X1) dan fleksibilitas (X2) terhadap Kinerja (Y1), dan menggunakan Kepuasan Kerja (Y2) sebagai bagian dari variabel intervening. Jenis penelitian yang digunakan adalah jenis penelitian kuantitatif. Populasi dalam penelitian ini adalah Driver Gojek asal Samarinda. Teknik pengambilan sampel yang digunakan adalah incidental sampling. Hasil perhitungan uji $\mathrm{t}$ (parsial) menunjukkan bahwa Kompensasi(X1) berpengaruh negatif dan tidak signifikan terhadap Kepuasan Kerja (Y2), dan Fleksibilitas (X2) berpengaruh positif dan signifikan terhadap Kepuasan Kerja (Y2), Kompensasi (X1 ) berpengaruh negatif dan tidak signifikan terhadap Kepuasan Kerja, Kinerja (Y1) dan Fleksibilitas (X2) berpengaruh positif dan tidak signifikan terhadap Kinerja (Y1), Kepuasan Kerja (Y2) berpengaruh positif dan tidak signifikan terhadap Kinerja (Y1).
\end{abstract}

Kata Kunci: Kompensasi, Fleksibilitas, Kinerja, Kepuasan Kerja

\section{ABSTRACT}

The effect of gojek driver compensation and flexibility on performance with job satisfaction as intervening variable at pt gojek indonesia samarinda branch. This study aims to determine the effect of independent variables consisting of compensation (X1) and flexibility (X2) on performance (Y1), and use Job Satisfaction (Y2) as part of the intervening variable. The type of research used is the type of quantitative research. The population in this study were Gojek drivers from Samarinda. The sampling technique used is incidental sampling. The results of the t-test calculation (partial) show that Compensation (X1) bas a negative and insignificant effect on Job Satisfaction (Y2), and Flexibility (X2) bas a positive and significant effect on Job Satisfaction (Y2), Compensation (X1) has a negative and insignificant effect on Job Satisfaction, Performance (Y1) and Flexibility (X2) have a positive and insignificant effect on Performance (Y1), Job Satisfaction (Y2) has a positive and insignificant effect on Performance (Y1).

Keywords: Compensation, Flexibility, Performance, Job Satisfaction 


\section{PENDAHULUAN}

Sumber Daya Manusia (SDM) bisa dikatakan memiliki peran yang sangat penting bagi perusahaan yaitu sebagai pengelola dan penggerak sebuah perusahaan. Menurut Milkovich et al. (2002) Kompensasi adalah bentuk pengembalian, layanan, dan keuntungan financial yang diterima pekerja sebagian dari hubungan kerja. Tidak hanya kompensasi didalam Sumber Daya Manusia (MSDM) pun terdapat fleksibilitas kerja menurut Carlson et al. (2010) Fleksibilitas merupakan kebijakan yang ditetapkan secara formal manajemen sumber daya manusia atau pengaturan informal yang terkait dengan fleksibilitas sebuah perusahaan. Lebih lanjut, Carlson mengartikan bahwa apa itu schedule flexsibility yaitu sebagai pengaturan kerja secara fleksibel yang berarti pemilihan tempat dan waktu untuk bekerja, baik formal atau informal, yang memfasilitasi karyawan dalam kebijakan berapa lama (time flexsibility), kapan (timing flexsibility), dan di mana (place flexsibility) karyawan bekerja. Dengan adanya kompensasi dan fleksibilitas dapat menimbulkan Kepuasan kerja (Job Satisfaction) menurut Wexley dan Yuki (2005) Kepuasan Kerja adalah "perasaan karyawan tentang pekerjaan mereka".

Emosi yang berhubungan dengan pekerjaan mencangkup aspek-aspek seperti upah dan gaji yang diterima, peluang pengembangan karir, hubungan dengan karyawan lain, lokasi, jenis kegiatan,struktur organisasi karyawan, dll perusahaan dan pemantauan kualitas. Maka kinerja pada karyawan akan memiliki hasil kerja yang baik Menurut Mangkunegara (2012) Kinerja adalah hasil kerja kualitatif dan kuantitatif yang dilakukan seorang karyawan dalam menyelesaikan tugasnya, sesuai dengan tanggung jawab yang diberikan kepadanya.

Teknologi yang menguntungkan bisnis, khususnya sumber daya manusia (SDM), erat kaitannya dengan starup di mana teknologi dan manusia menjadi motor penggerak utama bisnis, misalnya, perusahaan transportasi online yaitu Gojek yang layanan utamanya ada GORIDE, GOCAR dan GOFOOD dan masih banyak lainnya. Dampak positif dari hadirnya Gojek pada riset LD-FEB-UI 2018 seperti memberi peluang pekerjaan bagi yang tidak mengenyam pendidikan tinggi. Kehadiran gojek yang memberikan dampak positif dengan memberikan lapangan pekerjaan bagi masyarakat serta dapat meningkatkan penghasilan masyarakat yang bekerja menjadi driver Gojek.

Dari observasi awal secara langsung yang dilakukan peneliti ke 30 driver Gojek di Samarinda di Jl. Pramuka dan Mall Lembuswana, serta mahasiswa yang bekerja menjadi driver Gojek bahwa hampir dari keseluruhan driver merasa fleksibel bekerja di Gojek membuat mereka puas apalagi bagi driver yang yang menjadikan pekerjaan driver Gojek sebagai sampingan seperti mahasiswa dan pekerja kantoran mereka merasa waktu kerja yang fleksibel dapat membuat mereka berbagi kebutuhan pribadi dengan jam kerja, dan kompensasi yang ditawarkan Gojek dengan mengumpulkan 20 poin sehari. Pengemudi Gojek akan mendapatkan bonus RP 50.000. Peneliti tertarik untuk melanjutkan penelitian dengan

sampel yang lebih besar. Berdasarkan penjelasan di atas, peneliti tertarik untuk melanjutkan penelitian. Oleh karena itu, peneliti akan melakukan sebuah penelitian tentang "Pengaruh Kompensasi Dan Fleksibilitas Driver Gojek Terhadap Kinerja Dengan Kepuasan Kerja Sebagai Variabel Intervening Pada PT Gojek Indonesia Cabang Samarinda".

Berdasarkan paparan di atas maka, dirumuskan masalah yang akan diteliti yaitu: Seberapa besarnya pengaruh Kompensasi dan Fleksibilitas terhadap Kinerja setelah 
itu seberapa besar pengaruh Kompensasi dan Fleksibilitas terhadap Kepuasan Kerja driver Gojek pada PT Gojek Indonesia Cabang Samarinda?

\section{METODE PENELITIAN}

Dalam penelitian ini, jenis penelitian ini merupakan penelitian konfirmatori dengan pendekatan kuantitatif. Menurut Uma Sekaran (2013) menyatakan bahwa penelitian kuantitatif adalah metode ilmiah yang datanya berbentuk angka atau bilangan yang dapat diolah dan dianalisis dengan menggunakan perhitungan matematika atau statistika. Konfirmatori adalah analisis yang akan menemukan jumlah variabel indikator yang tidak dapat diukur langsung secara teori. Dari definisi metode penelitian yang dikemukakan maka dapat disimpulkan bahwa metode penelitian konfirmatori dengan pendekatan kuantitatif adalah metode ilmiah yang datanya berbentuk angka atau angka yang kemudian diolah menggunakan ilmu matematika yaitu statistika berlandaskan teori. Selanjutnya peneliti juga telah mendefinisikan defisi operasional untuk mempelajari variabel terukur.

1) Variabel Independen/Variabel Bebas $(X)$

Variabel Independen/Variabel Bebas (X) dari penelitian ini yaitu Kompensasi (X1) dan Fleksibilitas (X2). Kompensasi yang ingin diteliti disini adalah imbalan yang diterima sebagai balas jasa berbentuk Insentif Dan Fasilitas yang diberikan

PT Gojek Indonesia Cabang Samarinda terhadap driver Gojek. Sedangkan Fleksibilitas yang ingin diteliti disini adalah kebijakan formal yang diterapkan oleh manajemen sumber daya dengan pengaturan kerja yang fleksibel yang diberikan PT Gojek Indonesia Cabang Samarinda terhadap driver Gojek. Sugiyono (2014) menyatakan variabel bebas/variabel independen yaitu variabel yang akan memengaruhi atau yang akan terjadi dalam perubahan sesuatu pada variabel terikat (terbatas).

2) Variabel Dependen/Variabel Terikat (Y1)

Variabel Dependen/Variabel Terikat (Y1) adalah Kinerja (Y1). Kinerja yang ingin diteliti adalah hasil dari kemampuan dari seseorang driver Gojek dalam menjalankan tugasnya. Sugiyono (2014) menyakan bahwa variabel terikat/variabel dependen merupakan sebuah variabel yang dipengaruhi atau hasil dari variabel bebas.

3) Variabel Intervening (Y2)

Variabel Intervening (Y2) adalah Kepuasan Kerja (Y2). Kepuasan Kerja yang ingin diteliti adalah perasaan positif yang dirasakan

driver Gojek terhadap PT Gojek Indonesia Cabang Samarinda.

\begin{tabular}{|c|c|c|}
\hline Variabel & Indikator & Sub Indikator \\
\hline \multirow{2}{*}{$\begin{array}{l}\text { Kompensa } \\
\text { si } \\
\text { Simamora } \\
2004\end{array}$} & & $\begin{array}{l}\text { Kompensasi di atas atau di luar gaji yang } \\
\text { diterima driver Gojek }\end{array}$ \\
\hline & 2.Fasi & $\begin{array}{l}\text { Aplikasi driver,jaket, helm, adanya bengkel } \\
\text { yang bekerjasama dengan Gojek. }\end{array}$ \\
\hline \multirow{3}{*}{$\begin{array}{l}\text { Fleksibilita } \\
\text { s kerja } \\
\text { Carlson et } \\
\text { al. } 2010\end{array}$} & . 1. Tin & $\begin{array}{l}\text { Memodifikasi durasi kerja, kapan ingin bekerja } \\
\text { dan berapa lama waktu bekerja. }\end{array}$ \\
\hline & $\begin{array}{ll}2 . & \text { Timing } \\
\text { flexibility } & \end{array}$ & $\begin{array}{l}\text { Memilih jadwal kerja yang dinginkan oleh } \\
\text { driver Gojek. }\end{array}$ \\
\hline & 3. Place flexibility & Driver Gojek dapat Memilih tempat kerjanya \\
\hline
\end{tabular}




\begin{tabular}{|c|c|c|}
\hline \multirow{2}{*}{$\begin{array}{l}\text { kepuasan } \\
\text { kerja } \\
\text { Robbins } \\
2012\end{array}$} & $\begin{array}{l}\text { 1.Kondisi kerja } \\
\text { yang } \\
\text { mendukung }\end{array}$ & $\begin{array}{l}\text { Lingkungan yang baik dimana driver Gojek } \\
\text { diterima di semua kalangan. }\end{array}$ \\
\hline & $\begin{array}{l}\text { 2.Rekan Kerja } \\
\text { yang mendukung }\end{array}$ & Ada pesahabatan yang baik antar driver Gojek. \\
\hline \multirow[t]{5}{*}{$\begin{array}{l}\text { Mangkune } \\
\text { gara } 2012\end{array}$} & 1.Kualitas kerja & $\begin{array}{l}\text { Driver Gojek menyelesaikan proses pekerjaan } \\
\text { dengan baik ini dapat mengurangi kesalahan } \\
\text { dalam bekerja. }\end{array}$ \\
\hline & $\begin{array}{ll}2 . & \text { Kuantitas } \\
\text { Kerja } & \end{array}$ & $\begin{array}{l}\text { Driver Gojek mengerjakan pekerjaan dengan } \\
\text { dalam satu waktu dengan baik. }\end{array}$ \\
\hline & $\begin{array}{l}\text { 3.Tanggung } \\
\text { Jawab }\end{array}$ & $\begin{array}{l}\text { Kemampuan driver Gojek untuk bertanggung } \\
\text { jawab dari hasil pekerjaannya. }\end{array}$ \\
\hline & 4.Kerjasama & Adanya kerja sama antar Driver Gojek. \\
\hline & 5.Inisiatif & $\begin{array}{l}\text { Adanya inisiatif Driver Gojek dalam } \\
\text { menangani pekerjaanya. }\end{array}$ \\
\hline
\end{tabular}

\section{Populasi, Sampel dan Sampling}

Penelitian ini memiliki populasi sebanyak 116 orang. Metode yang digunakn yaitu incidental sampling. Sugiyono (2014) menyatakan bahwa teknik incidental sampling yaitu merupakan sebuah teknik penentuan sampel yang berdasarkan kebetulan yaitu siapa saja yang secara kebetulan bertemu dengan peneliti dan dapat digunakan sebagai sampel bila dipandang orang kebetulan ditemui itu cocok sebagai sumber data. Dalam penelitian ini peneliti menghitung ukuran sampel dengan menggunakan rumus Machin \& Campbell. Untuk mengetahui jumlah sampel peneliti menggunakan rumus Machin \& Campbell (1987) :

$$
\begin{aligned}
& U_{\rho}=\frac{1}{2} \ln \left[\begin{array}{lll}
\frac{1}{1} & \pm & \rho \\
\rho
\end{array}\right]+\frac{\rho}{2(n-1)} \\
& n=\frac{\left(Z_{1-\alpha}+Z_{1-\beta}\right)^{2}}{\left(U_{\rho}\right)^{2}}+3 \\
& U_{\rho}^{\prime}=\frac{1}{2} \ln \left[\frac{1}{1} \pm \frac{\rho}{\rho}\right]
\end{aligned}
$$

Keterangan : 
$U_{\rho}=$ variabel standar acak normal yang sesuai dengan nilai tertentu dari koefisien korelasi.

$$
\begin{aligned}
& U_{\rho}^{\prime}=\text { perkiraan awal } U_{\rho} \\
& \text { ln }=\text { log-e (natural logarithm) } \\
& n \quad=\text { ukuran sampel } \\
& \rho \quad=\text { koefisien korelasi yang diperkirakan oleh peneliti untuk }
\end{aligned}
$$
penelitian

$z_{1-\alpha}=$ nilai yang terdapat pada Tabel Distribusi Normal Buku dengan $\alpha$ yang ditentukan

$Z_{1-\beta}=$ nilai yang didapat dari Tabel Distribusi Normal Buku dengan $\beta$ yang ditentukan

Berdasarkan dari perkiraan ditetapkan nilai $\mathrm{r}$ terendah yang diperkirakan akan diperoleh dari penelitian ini yaitu $\mathrm{r}=0,30 ; \alpha=0,10$ pada pengujian dua arah dan $\beta$ $=0,05$ maka $\mathrm{n}$ (minimum) $=116$. Jadi sampel dalam penelitian ini memiliki jumlah 116 responden.

\section{Teknik Analisis}

kuesioner adalah metode pengumpulan data yang digunakan oleh peneliti dan menggunakan alat ukur skala likert yang digunakan untuk mengukur Kompensasi Dan Fleksibilitas Driver Gojek Terhadap Kinerja Dengan Kepuasan Kerja Sebagai Variabel Intervening Pada Pt Gojek Indonesia Cabang Samarinda dan menggunakan Berdasarkan hipotesis dan rumusan masalah, penelitian ini menerapkan metode data kuantitatif dan menggunakan tahapan dalam analisis yaitu: Uji Validitas, Uji Realibilitas, Uji Asumsi Klasik, Uji Regresi Linier Berganda, Uji Koefisien Korelasi, Uji Koefisien Determinasi, dan Uji Hipotesis.

\section{HASIL PENELITIAN}

\section{1) Uji Validitas}

Uji validitas kuesioner di gunakan untuk mengetahui keakuratan item yang ingin di teliti pada kuesioner. Dibantu program Software SPSS Versi 22 (Statistic Packagge For the Social SecienceI). Dari hasil pengujian diketahui bahwa seluruh butiran mempunyai koefisien $>$ dari $r_{\text {tabel }}$ (nilai $r_{\text {tabel }}$ untuk $\mathrm{N}=116$ sehingga $\mathrm{df}=116-2=114$ dengan menggunakan tingkat signifikansi dua arah $5 \%$ atau 0,05$)$ diperoleh nilai $r_{\text {tabel }}$ adalah 0,182$)$. Oleh sebab itu, semua pertanyaan dinyatakan valid.

\section{2) Uji Reabilitas}

Uji reliabilitas digunakan untuk mengetahui konsistensi alat ukur pada kuesioner, apakah alat ukur tersebut akan mendapat pengukuran yang tetap konsisten. Uji validitas dalam penelitian ini menggunakan program Software SPSS Versi 23 (Statistic Packagge For the Social SecienceI).

Berikut adalah hasil pengujian reliabilitas dari setiap variabel penelitian:

\begin{tabular}{|l|l|l|}
\hline Variabel & Cornbach's Alpha & Simpulan \\
\hline
\end{tabular}




\begin{tabular}{|l|l|l|}
\hline \hline $\mathrm{X} 1$ & 0,763 & Reliabel \\
\hline $\mathrm{X} 2$ & 0,793 & Reliabel \\
\hline Y1 & 0,771 & Reliabel \\
\hline Y2 & 0,772 & Reliabel \\
\hline
\end{tabular}

Sumber: Data diolah (2021)

Berdasarkan tabel diatas, nilai Combach's Alpha semua variabel > 0,60 Oleh karena itu, semua pertanyaan dinyatakan reliabel.

\section{Uji Asumsi Klasik}

\section{1) Uji Normalitas}

Dibantu dengan SPSS versi 22 menghasilkan hasil uji normalitas dengan cara melihat penyebaran data yang ada pada sumber diagonal pada bentuk grafik (chart) Normal P-P Plot Of Regression Standardized Residual menghasilkan data sebagai berikut:

\section{Berdasarkan gambar 4.4}

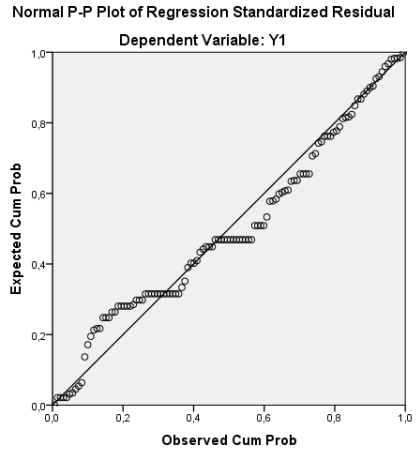

Sumber: Data diolah (Output SPSS), 2021

Grafik Normal Probability Plot, dapat dilihat bahwa pola penyebaran data yang berbentuk titik-titik atau lingkaran kecil tersebut menyebar mengikuti garis lurus diagonal disekitar diagram maka nilai dari residual tersebut telah normal.

2) Uji Multikolinearitas

Berdasarkan data yang diperoleh, diketahui bahwa nilai tolerance variabel X1 (kompensasi) dan X2 (fleksinilitas) masing-masing sebesar 0,985 dan nilai VIF nya sebesar 1,016. Dengan nilai tolerance $>0,10$ dan nilai VIF $<10$ menyebabkan data tidak terjadi multikolinearitas.

\section{3) Uji Heteroskedastisitas}

Berdasarkan pada hasil uji heteroskedastisitas dengan alat bantu SPSS versi 22 menghasilkan hasil sebagai berikut dengan basic pengambilan keputusan dalam uji heterokedastisitas grafik Scatterplot sebagai berikut :

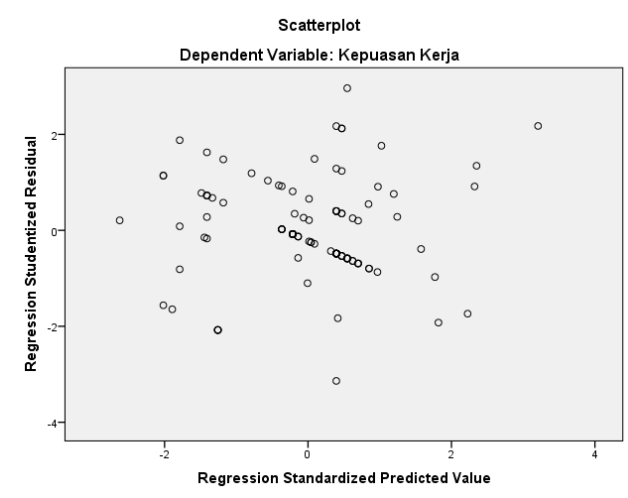


Sumber: Data diolah (Output SPSS), 2021

Berdasarkan gambar 4.5 Grafik Scatterplot, dapat dilihat pola penyebaran data yang berbentuk titik-titik atau lingkaran kecil tersebut menyebar secara merata tanpa adanya bentuk pola tertentu yang berarti tidak terjadi heteroskedastisitas.

1. Perhitungan Koefisien Korelasi (R)

Peneliti menggunakan perhitungan Koefisien korelasi untuk mencari apakah ada tidaknya hubungan antara variabel $(\mathrm{X})$ dan variabel $(\mathrm{Y})$. Diketahui bahwa nilai koefisien determinasi (R2) adalah 0,308 yang dimana interpretasi terhadap korelasi itu rendah. Persentase antara pengaruh kompensai dan fleksibilitas terhadap kinerja sebesar 30,8\%. Sedangkan sisa dari 100\% - 30,8\% = 69,2\% dipengaruhi variabel lain yang tidak diteliti oleh peneliti dalam penelitian ini.

\section{Uji Hipotesis}

1. Uji T

Untuk mengetahui apakah adanya pengaruh dari variabel independen yang ada terhadap variabel dependen secara parsial, maka dapat dilakukan melalui uji t. Untuk uji $\mathrm{t}$ dengan $\mathrm{t}_{\text {hitung, }}$, maka nilainya dibandingkan dengan ttabel, dengan kriteria sebagai berikut. Pada uji $\mathrm{t} \mathrm{X}_{1}, \mathrm{X}_{2}$ dan $\mathrm{Y}_{1}$ terdapat nilai $\mathrm{t}_{\text {hitung }} \mathrm{X}_{1}$ (Kompensasi) 2,490> $t_{\text {tabel }}$ 1,980 dan Sig. $t_{\text {hitung }} X_{1}$ (Kompensasi) 0,014> $\alpha$ 0,05 berarti variabel $X_{1}$ (Kompensasi) secara parsial berpengaruh secara signifikan terhadap variabel $\mathrm{Y}_{1}$ (Kepuasan Kerja). Kemudian pada uji t $Y_{1}$ dan $Y_{2}$ terdapat nilai $t_{\text {hitung }} Y_{1}$ (Kepuasan Kerja) 4,092 $>t_{\text {tabel }}$ 1,980 dan Sig. $t_{\text {hitung }} Y_{1}$ (Kepuasan Kerja), $000>\propto 0,05$ berarti variabel $Y_{1}($ Kepuasan Kerja) secara parsial berpengaruh secara signifikan terhadap variabel $\mathrm{Y}_{2}($ Kinerja).

2. Analisis Jalur (Path)

Analisis jalur dalam riset pemasaran secara teori sangat bermanfaat, Karena tidak seperti teknik lainnya, teknik ini memaksa peneliti untuk menentukan hubungan (korelasi) antara semua variabel independen. Biasanya, analisis jalur melibatkan konstruksi diagram jalur, dimana hubungan antara semua variabel dan arah sebab akibat di antara variabel ditata secara khusus. Saat melakukan analisis jalur, hal pertama yang peneliti lakukan mungkin membangun atau menggambar diagram jalur input, yang menggambarkan hubungan yang sudah dihipotesiskan. Dalam diagram jalur, penggunkan panah untuk menunjukkan bagaimana variabel yang berbeda saling berhubungan.

Berdasarkan persamaan struktural I dan II maka disimpulkan diagram jalur sebagai berikut:

Direct Effect/Pengaruh Langsung

Pengaruh $\mathrm{X}_{1}, \mathrm{X}_{2}$ terhadap $\mathrm{Y}_{1}$ dan dari $\mathrm{Y}_{1}$ terhadap $\mathrm{Y}_{2}$, atau lebih sederhananya disajikan seperti berikut.

$$
\begin{array}{lll}
\text { DEyx }_{1} & \mathrm{X}_{1} \longrightarrow \mathrm{Y}_{1} ; & \mathrm{Py}_{2} \mathrm{x}_{1}=0,196 \\
\text { DEyx2 } & \mathrm{X}_{2} \longrightarrow \mathrm{Y}_{1} ; & \mathrm{Py}_{2} \mathrm{x}_{2=}=0,495 \\
\text { DEzy } & \mathrm{Y}_{1} \longrightarrow \mathrm{Y}_{2} & \text { Py2y1 }=
\end{array}
$$

Indirect Effect/Pengaruh tidak langsung 
Indirect Effect/Pengaruh tidak langsung yaitu dari $\mathrm{X}_{1}$ terhadap $\mathrm{Y}_{2}$ melalui $\mathrm{Y}_{1}$ dan dari $\mathrm{X}_{2}$ terhadap $\mathrm{Y}_{2}$ melalui $\mathrm{Y}_{1}$ atau lebih sederhananya seperti berikut.

IEzy $_{1} x_{1}: X_{1} \longrightarrow Y_{1} \longrightarrow Y_{2} ; P_{1} x_{1}$. Py1y2 $=(0,196) \cdot(0,090)=0,017$

$\mathrm{IEzy}_{1} \mathrm{x}_{2}: \mathrm{X}_{2} \longrightarrow \mathrm{Y}_{1} \longrightarrow \mathrm{Y}_{2} ; \mathrm{Pyx}_{2} \cdot \mathrm{Py} 1 \mathrm{y} 2=(0,495) \cdot(0,090)=0,044$

Total Effect/Pengaruh Total

Pengaruh Total/Total Effect adalah penjumlahan DE dan IE (DE + IE) sebagai berikut.
$\mathrm{TE}_{11}=\mathrm{DEyx}_{1}+$ Iey1y2x1
$(0,196)+(0,017) \quad=0,213$
$\mathrm{TE}_{12}=\mathrm{DEyx}_{2}+$ Iey1y2x2
$(0,495)+(0,044) \quad=0,585$
$\mathrm{TE}_{21}=$ Dey1y2
$=0,090$

1) Pengaruh Kompensasi Terhadap Kinerja

Hasil yang diperoleh dalam pengujian ini menunjukkan kompensasi sebesar ,065 dengan signifikansi sebesar 0,570<0,05. Artinya model analisis jalur dalam penelitian ini berpengaruh negatif sebesar -,065 dan tidak signifikan terhadap kepuasan kinerja. Oleh sebab itu, hipotesis 1 yaitu kompensasi memiliki pengaruh positif serta juga signifikan terhadap kinerja pada PT Gojek Indonesia Cabang Samarinda ditolak.

2) Pengaruh Fleksibilitas Terhadap Kinerja

Hasil pengujian menunjukkan fleksibilitas sebesar 0,812 dengan signifikansi sebesar $0,000<0,05$. Artinya model analisis jalur dalam penelitian ini berpengaruh positif sebesar 0,812 dan signifikan terhadap kinerja. Oleh karena itu, hipotesis 2 yang menyatakan bahwa fleksibilitas berpengaruh positif dan juga signifikan terhadap kepuasan kerja pada PT Gojek Indonesia Cabang Samarinda diterima.

3) Pengaruh Kompensasi Terhadap Kepuasan Kerja

Hasil pengujian menunjukkan kompensasi sebesar 0,114 dengan signifikansi sebesar $0,014>0,05$. Artinya model analisis jalur dalam penelitian ini berpengaruh positif sebesar 0,114 dan tidak signifikan terhadap kepuasan kerja. Oleh sebab itu, hipotesis 3 yang menyatakan bahwa kompensasi berpengaruh positif dan tidak signifikan terhadap kepuasan kerja pada PT Gojek Indonesia Cabang Samarinda ditolak.

4) Pengaruh fleksibilitas Terhadap kepuasan kerja

Hasil pengujian menunjukkan fleksibilitas sebesar 0,301 dengan signifikansi sebesar $0,000<0,05$. Artinya model analisis jalur dalam penelitian ini berpengaruh positif sebesar 0,301 dan signifikan terhadap kepuasan kerja. Oleh karena itu hipotesis 4 yang menyatakan bahwa fleksibilitas berpengaruh positif dan signifikan terhadap kepuasan kerja pada PT Gojek Indonesia Cabang Samarinda diterima.

5) Pengaruh kepuasan kerja Terhadap kinerja

Hasil pengujian menunjukkan kepuasan kerja sebesar 0,233 dengan signifikansi sebesar $0,331<0,05$. Artinya model analisis jalur dalam penelitian ini berpengaruh positif sebesar 0,233 dan tidak signifikan terhadap kinerja. Oleh karena itu, hipotesis 5 yang menyatakan bahwa kepuasan kerja berpengaruh positif dan signifikan terhadap kepuasan kerja pada PT Gojek Indonesia Cabang Samarinda ditolak. 


\section{PEMBAHASAN}

1) Pengaruh Kompensasi Terhadap Kepuasan Kerja Berdasarkan dari tabel Coefficienta bahwa Kompensasi berpengaruh positif dan tidak signifikan terhadap Kepuasan Kerja. Artinya kompensasi berpengaruh efektif terhadap kepuasan kerja. Hal ini sejalan dengan penelitian yang dilakukan Imam Syaiful Wicaksono (2019) yang mengatakan bahwa kompensasi mempunyai pengaruh positif terhadap kepuasan kerja. Adapun bentuk perhitungan kompensasi bagi driver Gojek melalui sistem poin dari 1 poin hingan 3 poin pada setiap orderan yang diterima. Jika driver Gojek mendapatkan 20 poin per hari maka driver Gojek akan diberikan bonus Rp.40.000. Berdasarkan fakta dilapangan, tanggapan responden mengenai kompensasi bahwa mayoritas mengatakan tidak setuju pada kompensasi yang telah diberikan oleh PT Gojek Indonesia Cabang Samarinda itu sendiri pada setiap butir pernyataan kuesioner. Fakta ini disebabkan ketidakpuasan responden terhadap kompensasi yang diterima selama ini dari wawancara singkat yang dilakukan peneliti alasan dari responden tidak puas dikarenakan skema poin yang berubah seperti dari 20 poin mendapat insentif sebesar Rp 50.000 turun menjadi Rp 40.000.

2) Pengaruh Fleksibilitas Terhadap Kepuasan Kerja

Berdasarkan dari tabel Coefficienta bahwa Fleksibilitas berpengaruh positif serta signifikan terhadap Kepuasan Kerja. Artinya fleksibilitas memiliki pengaruh yang efektif terhadap kepuasan kerja. Hal ini sejalan dengan penelitian yang dilakukan Imam Syaiful Wicaksono (2019) yang mengatakan bahwa fleksibilitas kerja mempunyai pengaruh yang positif terhadap kepuasan kerja. Adapun bentuk fleksibilitas kerja dari driver Gojek yaitu dapat menentukan sendiri kapan untuk memulai berkerja dan driver Gojek memiliki waktu kerja maksimal 8 jam se hari tidak hanya itu driver Gojek juga dapat menentukan di mana tempat bekerja. Ukuran kinerja driver dapat di lihat di aplikasi Gopartner pada kualitas performa penilaiannya dapat dilihat dari rata-rata peforma harian dan sistem perhitungan kinerja dapat dilihat dari kualitas rating yang diberikan oleh pelanggan kepada driver selama 30 hari terakhir. Berdasarkan fakta dilapangan, tanggapan responden mengenai fleksibilitas bahwa mayoritas mengatakan setuju pada fleksibilitas yang diberikan PT Gojek Indonesia Cabang Samarinda pada setiap butir pernyataan kuesioner. Fakta ini juga didukung dari wawancaram singkat yang dilakukan peneliti dimana driver Gojek dapat mematikan layanan aplikasi diwaktu yang memungkinkan seperti saat hujan deras atau banjir karena driver Gojek tidak mau menerima orderan saat hujan dan banjir.

3) Pengaruh Kompensasi Terhadap Kinerja

Berdasarkan hasil dari tabel Coefficienta bahwa Kompensasi berpengaruh negatif dan tidak signifikan terhadap Kinerja. Artinya Kompensasi tidak memiliki pengaruh yang efektif terhadap Kinerja. Hal ini tidak sejalan dengan penelitian yang dilakukan Imam Syaiful Wicaksono (2019) dan Nurul Hidayah (2016) yang mengatakan bahwa kompensasi mempunyai pengaruh positif terhadap kinerja. Berdasarkan fakta dilapangan, tanggapan responden mengenai kompensasi bahwa mayoritas mengatakan tidak setuju pada kompensasi yang diberikan PT Gojek Indonesia Cabang Samarinda pada setiap butir pernyataan kuesioner. Fakta ini disebabkan ketidakpuasan responden terhadap Kompensasi yang diterima selama ini dari wawancara singkat yang dilakukan peneliti alasan dari responden tidak puas dikarenakan sistem poin yang dirasa kurang dari Kinerja yang mereka lakukan. 
4) Pengaruh Fleksibilitas terhadap Kinerja

Berdasarkan hasil dari perhitungan analisis jalur tabel Coefficienta bahwa Fleksibilitas berpengaruh positif dan tidak signifikan terhadap Kinerja. Artinya Fleksibilitas memiliki pengaruh yang efektif terhadap Kinerja. Hal ini sejalan dengan penelitian yang dilakukan Imam Syaiful Wicaksono (2019) yang mengatakan bahwa fleksibilitas kerja mempunyai pengaruh positif terhadap kinerja. Berdasarkan fakta dilapangan, tanggapan responden mengenai fleksibilitas bahwa mayoritas mengatakan setuju pada fleksibilitas yang diberikan PT Gojek Indonesia Cabang Samarinda pada setiap butir pernyataan kuesioner. Fakta ini menunjukkan bahwa responden menyetujui bahwa Fleksibilitas dapat mempengaruhi Kinerja.

5) Hubungan Kompensasi Dan Fleksibilitas

Berdasarkan hasil analisis jalur tabel Corelattion bahwa antara Kompensasi dan Fleksibilitas memiliki tingkat keeratan hubungan dalam kategori sangat rendah dan signifikan.

6) Pengaruh Kepuasan Kerja Terhadap Kinerja

Berdasarkan hasil analisis jalur tabel Coefficienta bahwa Kepuasan Kerja berpengaruh positif serta tidak signifikan terhadap Kinerja. Artinya Kepuasan Kerja memiliki pengaruh yang efektif terhadap Kinerja. Hal ini sejalan dengan penelitian yang dilakukan Imam Syaiful Wicaksono (2019) yang mengatakan bahwa kepuasan kerja mempunyai pengaruh positif terhadap kinerja. Berdasarkan fakta dilapangan, tanggapan responden mengenai kepuasan kerja bahwa mayoritas mengatakan setuju pada Kepuasan Kerja pada setiap butir pernyataan kuesioner. Fakta ini menunjukkan bahwa responden menyetujui bahwa Kepuasan Kerja dapat mempengaruhi Kinerja.

\section{KESIMPULAN}

Berdasarkan pada analisis dan pembahasan yang telah dilakukan, maka dapat diambil kesimpulan sebagai berikut:

1) Kompensasi berpengaruh positif dan tidak signifikan terhadap Kepuasan Kerja. Artinya Kompensasi memiliki pengaruh yang efektif terhadap Kepuasan Kerja. Hal ini sejalan dengan hipotesis peneliti sebelumnya dan ini menyiratkan bahwa Kompensasi memiliki pengaruh terhadap Kepuasan Kerja.

2) Fleksibilitas berpengaruh positif serta signifikan terhadap Kepuasan Kerja. Artinya Fleksibilitas memiliki pengaruh yang efektif terhadap Kepuasan Kerja. Hal ini sejalan dengan hipotesis peneliti sebelumnya dan ini menyiratkan bahwa Fleksibilitas memiliki pengaruh terhadap kepuasan kerja.

3) Kompensasi berpengaruh negatif dan tidak signifikan terhadap Kinerja. Artinya Kompensasi tidak memiliki pengaruh yang efektif terhadap Kinerja. Hal ini tidak sejalan dengan hipotesis peneliti sebelumnya dan ini menyiratkan bahwa Kompensasi tidak memiliki pengaruh terhadap Kepuasan Kerja.

4) Fleksibilitas berpengaruh positif dan tidak signifikan terhadap Kinerja. Artinya Fleksibilitas memiliki pengaruh yang efektif terhadap Kinerja. Hal ini sejalan dengan hipotesis peneliti sebelumnya dan ini menyiratkan bahwa Fleksibilitas memiliki pengaruh terhadap kinerja.

5) Kompensasi dan Fleksibilitas memiliki tingkat keeratan hubungan dalam kategori sangat rendah dan signifikan.

6) Kepuasan kerja berpengaruh positif dan tidak signifikan terhadap Kinerja. Artinya kepuasan kerja memiliki pengaruh yang efektif terhadap Kinerja. Hal ini sejalan 
dengan hipotesis peneliti sebelumnya dan ini menyiratkan bahwa Kepuasan Kerja memiliki pengaruh terhadap Kinerja.

\section{SARAN}

1) Bagi perusahaan, Kompensasi sangat penting untuk menunjang Kinerja driver Gojek maka perlu adanya perhatian khusus dengan menaikkan pendapatan dari insentif poin yang diperoleh oleh driver Gojek seperti mengembalikan skema poin dari perolehan maksimal 20 poin yang baru diterapkan $\mathrm{Rp} 40.000$ kembali menjadi Rp 50.000. Meskipun variabel kompensasi merupakan variabel yang berpengaruh negatif terhadap kinerja driver Gojek, akan tetapi perusahaan juga perlu memberikan perhatian serta meningkatkan faktor lain yang dapat memengaruhi Kepuasan Kerja yang positif bagi driver Gojek baik dari faktor Fleksibilitas maupun Kepuasan Kerja driver Gojek.

2) Bagi penelitian selanjutnya, diharapkan penelitian ini dapat dimanfaatkan sebagai bahan referensi dalam melakukan penelitian selanjutnya.

\section{DAFTAR PUSTAKA}

Abdullah, M. (2014). Manajemen dan Evaluasi Kinerja Karyawan. Yogyakarta: Aswaja Pressindo.

Akma, A. \&. (2015). Pengaruh Kompensasi Terhadap Kepuasan Kerja Karyawan Gayamakmur Mobil Medan.

Bangun, W. (2012). Manajemen Sumber Daya Manusia. Jakarta: Erlangga.

Bougie, \&. S. (2013. Edisi 5, Research Methods for Business: A skill Building Approach. New York: John wiley@Sons.

Hasil Risel Nilsen Indonesia 2019. Diakses pada 10 juli 2020

https://kumparan.com/kumparanbisnis/riset-nielsen-gofood-dominasiaplikasi-pesan-antar-makanan-di-ri-1rtnOnORGLE

Carlson, D. S. (2010). Carlson, D. , Grzywacz, J. dan Michele Kacmar, K. (2010), "Hubungan fleksibilitas jadwal dan hasil melalui antarmuka kerja-keluarga". Jurnal Psikologi Manajerial, 330-335.

Daryanto, B. \&. (2017). Manajemen Penilaian Kinerja Karyawan. Yokyakarta: Grava Media.

Dessler, G. (2010 ). Manajemen Sumber Daya Manusia. Jakarta Barat: PT Indeks.

Edison Emron, Y. A. (2016). Manajemen Sumber Daya Manusia. Bandung: Alfabeta.

Eko, W. S. (2015). Manajemen Pengembangan Sumber Daya Manusia. Yogyakarta: PUSTAKA PELAJAR.

Ghozali, I. (2011). Aplikasi Analisis Multivariate Dengan Program SPSS. Semarang: Badan Penerbit Universitas Diponegoro.

Handoko, T. H. (2014). Manajemen Personalia dan Sumber Daya Manusia. Yogyakarta: BPFE.

Hasibuan, M. S. (2016 ). Manajemen Sumber Daya Manusia. Edisi Revisi. Jakarta: PT Bumi Aksara.

Hidayah, N. (2016). Pengaruh Kompensasi Terhadap Kinerja Karyawan Dengan Kepuasan Kerja Sebagai Variabel Intervening (Studi Kasus Pada Karyawan Bagian Keuangan Dan Akuntansi Uny). 12.

Juniantara, I. W. (2015). Pengaruh Motivasi Dan Kepuasan Kerja Terhadap Kinerja Karyawan Koperasi Di Denpasar. 18.

Kadarisman, M. (2012). Manajemen kompensasi. Jakarta: Rajawali Pers. 
Kristine, E. (2017). Pengaruh Kepuasan Kerja Dan Komitmen Organisasi Terhadap Kinerja Melalui Motivasi Kerja Pegawai Alih Daya (Outsourcing) Di Pt. Mitra Karya Jaya Sentosa. 18.

Mangkunegara, A. P. (2012). Manajemen Sumber Daya Manusia. Bandung: PT. Remaja Rosdakarya.

Marwansyah. (2016). Manajemen Sumber Daya Manusia. Edisi Dua. Cetakan keempat. Bandung: Alfabeta,CV.

Milkovich, G. d. (2002). Compensation. 7. Amerika: Mc Grow-Hill Irwin.

Nawawi. (2011). Manajemen Sumber Daya Manusia: Untuk Bisnis Yang Kompetitif. Yogyakarta: Gajahmada University Press.

Nuraini, D. (2017). Pengaruh Fleksibilitas Kerja Dan Spesialisasi Pekerjaan Terhadap Kinerja Karyawan Dengan Kepuasan Kerja Sebagai Variabel Mediating Pada Pt. Daya Manunggal Salatiga. 26.

Priyatno, D. (2017). Panduan Praktis Olah Data Menggunakan SPSS. Yogyakarta: Andi.Perhitungan Sistem Gaji Gojek 2019. Diakses pada 12 Oktober 2019. www.infokerjakuu.com/sistem-gaji-gojek/

Rivai, V. s. (2013). manajemen sumber daya manusia untuk perusabaan dari teori ke praktik. Jakarta: PT. Raja Grafindo Persada.

Robbins, P. d. (2012). Perilaku Organisasi. Jakarta: Salemba Empat.

Robbins, P. S. (2010). Manajemen, diterjemabkan oleb Bob Sabran, Wibi Hardani. Jakarta: Erlangga.

Samsudin, S. (2012). Manajemen Sumber Daya Manusia. Bandung: Pustaka Setia.

Shagvaliyeva, S. \&. (2014). Impact of flexible working hours on worklife balance. Journal of Industrial and Bussines Management American, 20-23.

Simamora, H. (Manajemen Sumber Daya Manusia). 2004. Yogyakarta: STIE YKPN.

Sofyandi, H. (2013). manajemen sumber daya manusia. Yogyakarta: Graha Ilmu.

Sugiyono. (2014). Metode Penelitian Pendidikan Pendekatan Kuantitatif, Kualitatif, dan R®D. Bandung: Alfabeta.

Sunariah, K. \&. ( 2013). Panduan Modern Penelitian Kuantitatif. Bandung: Alfabeta.

Walandouw, P. d. (2018). Dampak GOJEK terhadap Perekonomian Indonesia di 2018. 36.

Wexley KN, \&. Y. (2005). Perilaku organisasi dan psikologi personalia. Jakarta: Bina Aksara.

Wibowo. (2011). Manajemen kinerja. Jakarta: PT. Raja Grafindo Persada.

Wicaksono, I. S. (2019). Pengaruh Kompensasi Dan Fleksibilitas Kerja Terhadap Kinerja Driver Gojek Dengan Kepuasan Kerja Sebagai Variabel Intervening. 42.

Juanim (2020). Analisis Jalur Dalam Riset Pemasaran pengolahan Data SPSS \& LISREL 